been printed in detail or abstracted. Most readers are perhaps more interested in the work and writings of former surgeons than in a short biography of their lives, especially as urology is a speciality which has changed remarkably with the modern aids of endoscopy and radiography. However, we read of Harry Fenwick's introduction of the cystoscope to Britain in 1888 and of his radio-opaque bougie in 1905. Sir Peter Freyer's first prostatectomy in 1900 is mentioned in some detail, together with some other fascinating titbits of his life. Other well-known figures in urology appear only in outline.

After a short chapter on the non-surgical members of the staff and the clinical assistants, there follows another by Harkness on the V.D. department, which owes so much to his work there.

The final chapter on the nursing staff reminds the reader with force of the changes in nursing care since i 860 when the Nightingale training school opened. The first woman with hospital training was appointed to St. Peter's in 1876 . Until that date the matron earned about $£ 30$ per annum plus $£_{3}$ I 5 s. od. beer money. In 1919 a Sister worked from 8.30 a.m. until about 12 midnight, with a salary of $£ 44$ per annum, and a Nurse from 7 a.m. to 8.30 p.m. with one hour off duty. In 1960 the first bath for nurses and residents was installed (and is still in use).

This is a short account of the history of St. Peter's Hospital for the Stone, including biographies of the staff. It makes fascinating reading, especially for those interested in urology and in particular those who have trained and worked at St. Peter's. Clifford Morson and the editorial committee are to be congratulated.

\section{CIBA Foundation Colloquia on Endocrinology}

Vol. 13. Human Pituitary Hormones. Editors: G. E. W. Wolstenholme; Celia M. O'Connor. Pp. 336, with 86 illustrations. London: J. \& A. Churchill Ltd. 1960. 50 s.

The papers presented in this volume are those which were read at a Colloquium held in the Argentine in honour of Professor B. A. Houssay. As usual the full text of each paper is included, with illustrations, and the discussion which ensued is also printed. This method enables those interested in the subject but unable to spare either the time or money to travel to South America to benefit from the proceedings: it also enables those who were present to read the papers at leisure. There are 16 communications in all, of which seven deal with growth hormone in various aspects, two with urinary hormone assays, and only one with thyrotropic hormone; there are also two papers on the chemical structure of human Melanocyte Stimulating Hormone. From the clinician's point of view, the first communication by Dr. Joplin and Professor Russell Fraser on the Radiological Anatomy of the Human Pituitary is probably the most interesting. This deals with the implantation of radioactive seeds in the gland. The standard of papers is high and the work can be recommended to all those interested in the pituitary gland and more particularly to research workers.

\section{Obstetrical and Gynæcological Pathology for Postgraduate Students}

R. E. REWELl, M..(LOND.), M.R.C.P. P. xii + 435, illustrated. Edinburgh and London: E. \& S. Livingstone Ltd. I960. 50 .

This book is written for the specialist. The author devotes the first ten chapters to gynæcological pathology, and gives excellent accounts of the histological appearances of the various lesions. His approach to the subject is not the standard textbook one but instead he presents his interpretation of each condition on theे basis of his own experience, and then describes the views of other workers, quoting a prolific number of references. In this section his reviews of the menstrua? cycle and of malignant diseases of the uterus are first. class, but his presentation of vulval diseases is inade quate. His descriptions of relevant dermatological state and leukoplakia are incomplete, whilst kraurosis vulvæ is barely mentioned and does not even appear in thes index. Hidradenoma is omitted entirely.

In Chapter I I a good account is given of vagina $\frac{\omega}{D}$ cytology and smear techniques. Chapters 12 to 100 concern obstetrical conditions and it is evident that the author is not so expert with this subject; his frequent? excursions into obstetric physiology and clinical patho logy show the work of the practitioner rather than thetouch of the master. However, he again quotes manyw references and these are a useful guide to the serious reader.

The book contains 150 illustrations, most of them microscopic sections. In general, however, these lack. clarity because they are too small. Despite somev spelling mistakes the author's style is eminently read i able, and his opinions are obviously sincerely based on the sections he has personally examined. The book is beautifully produced and can be recommended to post $\vec{\sim}$ graduate students and pathologists.

\section{The Practice of Medicine}

Editor: Sir John Richardson, M.v.o. Second $\overrightarrow{{ }_{1}}$ edition. Pp. viii +973 , illustrated. London $\triangle D$ J. \& A. Churchill Ltd. 1960. 37s. $6 d$.

The second edition of this book is shorter than first and this must be considered quite an achievemest. The editor makes it quite clear that the book is undergraduates and possibly general practitioners, there is no doubt that it contains a vast amount ${ }^{3}$ f factual material in a small space; whether sufficiento emphasis is placed on clinical signs and symptoms is doubtful, and the apparent lack of controversy or difficulties in the diagnosis, ætiology and managemen may lead the undiscerning student astray if he wishes to be aware of some of the problems which will con $\frac{\mathbb{D}}{2}$ front him. It is for this reason that a guide to further reading is welcomed at the end of each chapter although there are some notable omissions; thus, after the com 3 pletely inadequate chapter on bone disease which? consists of seven pages of oversimplified fact, interesting references are not considered necessary, and this gives the impression that there is no more to be said on the subject. Similarly reading of larger works should havebeen recommended in the subjects of immunity and collagen diseases at the end of these chapters.

Further difficulties in producing such a concise and factual book are shown by the somewhat incongruous balance of information allotted to various subjects; for 5 who could doubt that the approximately equal amount of space taken up in discussing essential hypertension and phæeochromocytoma bears any relation to the case? that any doctor will see. On the other hand, the chapters on endocrine diseases, chest diseases and somes others are excellent. There are one or two errors in proof-reading such as the spelling of tonsillitis and hypoglycæmia; an X-ray is reproduced upside down (page 239), and there are occasional terms of doubtfub

However, these points must not detract from the fact that this is an excellent book of its type and must take its place amongst the textbooks of medicine preferrect? by students and general practitioners at very reason-
able cost. 